\title{
Aleksei Losev and VeKHI: \\ Strategic Traditions in Social Philosophy
}

Elena Takho-Godi ${ }^{1}$

Aleksei Fedorovich Losev, one of the last representatives of nineteenth- and early twentieth-century Russian religious philosophy, did not take part in the Vekhi project: when Vekhi was published he was still at school. We might then ask whether it is legitimate to speak of Losev's connection to Vekhi. In my view it is indeed both legitimate and interesting to do so, first because Losev became personally acquainted with several of the Vekhi contributors not long after it was published, and second (and more importantly) because he inherited the social-philosophical strategy of Vekhi, which may be defined as opposition to the cause of revolution by means of the word or creative activity (the word-slovo-is here placed in opposition to the deeddelo). This position is most explicitly formulated in Mikhail Gershenzon's essay "Tvorcheskoe samosoznanie" ("Creative Self-Consciousness") and Semen Frank's essay "Etika nigilizma" ("The Ethics of Nihilism”), both of which explain the difference between what Frank calls creative "cultural production" and "principled revolutionism" (184), with its emphasis on social struggle and the destruction of existing social forms. ${ }^{2}$ This leitmotif can also be discerned in the works of other Vekhi contributors. Thus Petr Struve, in his essay "Intelligentsiia i revoliutsiia" ("The Intelligentsia and Revolution"), stresses that the liberal intelligentsia which led the revolution has never been able to comprehend the field of Russian literature, that is, precisely the sphere of the word (156). In this context, the accentuation of the merits of the literary and artistic spheres that is typical for Russian philosophy acquires a special meaning. The Vekhi authors wanted to transform the inner nature of the Russian intelligentsia through the word, 
through their social-philosophical public discourse, to arouse its creative self-consciousness. It was the "creative struggle of ideas" (166), as Struve put it, spiritual opposition, and the ascetic struggle (podvizhnichestvo) that were important to them, not the "heroism" or titanism of the social struggle of the revolutionary superman who had taken upon himself the task of destroying those with differing views in order to create a new social order.

\section{Aleksei LoSeV (1893-1988): Life ANd WORKS}

Aleksei Losev was born in Novocherkassk, in southern Russia. ${ }^{3}$ In 1911, after finishing his secondary education at a classical gymnasium and graduating from the Italian F. Stadzhi's music school, he matriculated at Moscow University in both the department of philosophy and the department of classical philology. An interest in psychology led him to the Psychological Institute founded by Professor Georgii Chelpanov. Thanks to Chelpanov's support, in the 1910s Losev became a participant in the famous Religious-Philosophical Society, which was established in memory of Vladimir Solov'ev in 1905. In 1915 Viacheslav Ivanov, the symbolist poet and classical philologist, read Losev's graduation thesis on Aeschylus. Losev was retained at the University to train for the academic profession, and his first publications appeared in 1916: articles on eros in Plato and the operas of Verdi and Rimskii-Korsakov. In the revolutionary year of 1919 he was a professor at the University of Nizhegorod. In the 1920s he was a full member of the State Academy of Artistic Sciences and a professor at the Moscow Conservatory and the State Institute of Musical Science. During this time Losev wrote and published no fewer than eight books, which were received by his contemporaries as "a new Russian philosophical system": ${ }^{4}$ Antichnyi kosmos i sovremennaia nauka (The Ancient Cosmos and Modern Science), Filosofiia imeni (The Philosophy of the Name), Dialektika khudozhestvennoi formy (The Dialectics of Artistic Form), and Musyka kak predmet logiki (Music as an Object of Logic), all in 1927; and Dialektika chisla u Plotina (The Dialectics of Number in Plotinus, 1928); Kritika platonizma u Aristotelia (Aristotle's Critique of Platonism, 1929); and Ocherki antichnogo simvolizma i mifologii (Essays on Classical Symbolism and Mythology) and Dialektika mifa (The Dialectics of Myth), both in 1930. 
The poet Andrei Belyi recorded in his diary his first impressions of Essays on Classical Symbolism and Mythology on 12 February 1930:

An enormous volume, more than 800 pages, it leaves a splendid impression. One can be proud that such a book has appeared in Russia at such a time. It is principally devoted to Plato. On a cursory reading (I'll give it proper attention later) you can see that this is not Frank, Berdiaev, or the like: genuine, original thought, extremely valuable material, and simple and modest in tone. I consider that at another time Losev's book would have created the same reaction in Russia as Spengler's did in Germany, but Losev's thought, so it seems to me, is more monumental. Losev is a genuine philosopher in the good sense of the word, and as a living philosopher he doesn't "philosophize" or "terminologize," but thinks. For now I write this in anticipation, because I've just sniffed at the book: I'll read it properly, but I have a good sense of smell. ${ }^{5}$

Although Essays on Classical Symbolism and Mythology, which had so impressed Belyi, went generally unnoticed, The Dialectics of Myth created quite a stir. ${ }^{6}$ Here Losev set himself an impossible task in the Soviet context: namely that of writing a philosophical-theological treatise on absolute mythology - on the Holy Trinity, the concept of the angel, the symbolism of immaterial powers, and so forth. ${ }^{7}$ Moreover, Losev's understanding of myth itself, as "the essential ontological identity of being and consciousness, whereby all being is fundamentally one or another manifestation of consciousness (not according to its arbitrary appearance, but in its ultimate substance) and whereby all consciousness is being (in the same way)," became the particular key to Losev's analysis of the sociopolitical system and mass psychology of the time. ${ }^{8}$ Losev demonstrated how socialism, that new relativist mythology with its cult of the material, its idea of the intensification of class struggle, and so forth, distorts personal and social consciousness. It is unsurprising that after the appearance of The Dialectics of Myth Losev was not only subjected to persecution in the press (a campaign in which Maksim Gor'kii participated) and condemned at the $16^{\text {th }}$ Party Congress as an enemy of the people, but was also arrested on 18 April 1930, and subsequently sent to a concentration camp for the construction of the White Sea-Baltic canal. In 1931, Nathalie Duddington, in a review of Russian philosophy for the English Journal of Philosophical Studies, informed the European public of the "bad news" concerning the 
philosopher Losev, "of whom Russia could be proud" and whose profound works of metaphysics had been declared counter-revolutionary. ${ }^{9}$ Losev himself, however, pondering on what had happened, wrote to his wife from the camp on 11 March 1932 that, suffocating "from the impossibility of expressing myself and speaking my mind," he had no longer felt able "to confine myself within the iron bands of Soviet censorship": "I knew that it was dangerous, but for a philosopher and writer the desire to express oneself, to let's one's individuality speak out, surmounts all consideration of danger." ${ }^{10}$

In 1933, following the completion of the canal, Losev's sentence was lifted, along with those of hundreds of other prisoners involved in the construction. He returned to Moscow, but was forbidden from engaging in philosophy: access to publication was completely blocked for him until 1953 and the death of Stalin. Under the conditions of the spiritual underground, in this quarter-century of enforced silence, Losev continued to write. Drawing on the doctrine of the Divine Energies formulated in the fourteenth century by Gregory Palamas (the knowledge of God through His energy) and on the religious-philosophical name-worshipping movement (onomatodoxia) of the early twentieth century (among the adherents of which was Pavel Florenskii), Losev developed a doctrine of the name that he had first begun in his book The Philosophy of the Name, in the essays "Veshch' i imia" ("The Thing and the Name") and "Samoe Samo" ("Self Itself"). Losev's basic concepts come to the fore in these works: thing, being, meaning, the depths of the eidos, "selfness" (samost'), and "self itself" (samoe samo), which should be understood as "the essence of the very essence of being," "11 "the most genuine, most insuperable, most terrible and potent reality that can possibly exist," ${ }^{2}$ which engenders "innumerable interpretations." ${ }^{13}$ During the same period Losev wrote works on the philosophy of mathematics (he had received a professional mathematical education in the 1920s from the prominent professor of mathematics Dmitrii Fedorovich Egorov, and through his correspondence with Nikolai Luzin, another outstanding mathematician). Among the themes most important to him were the analysis of the infinitesimal, the theory of multiples, and the theory of the complex variable. ${ }^{14}$ He translated Plato, Plotinus, Sextus Empiricus, Proclus, and Nicholas of Cusa, and studied 
Classical mythology. He created an original philosophical literary prose, displayed in his novel Zhenshchina-myslitel' (The Woman-Philosopher), in which the ideas of Solov'ev and the traditions of Dostoevskii are refracted in a distinctive way, ${ }^{15}$ and earned a living teaching Classical literature in provincial universities. Only during the war years (1942-44) was he allowed to read lectures in Moscow University's faculty of philosophy, and he was soon forced out after being denounced as an idealist. From this time until his death Losev worked in the Moscow State Pedagogical Institute in the departments of Russian language and general linguistics.

In the 1960s, 1970s, and 1980s Losev turned once more to the philosophy of symbol and myth, in Problema simvola $i$ realisticheskoe iskusstvo (The Problem of the Symbol and Realistic Art, 1976), and Znak. Simvol. Mif (Sign. Symbol. Myth, 1982), and to language, in Vvedenie v obshchuiu teoriiu iazykovykh modelei (Introduction to the General Theory of Linguistic Models, 1968), and Iazykovaia struktura (Linguistic Structure, 1983). His works on language raised the question of the possibility of a strict axiomatics in linguistics, and foregrounded communicative and interpretative acts. The author of The Philosophy of the Name, having traced the ladder of "naming" (imenitsvo) from the Divine Name down to the sound that is not yet illuminated by meaning, was convinced that two spheres of thought exist. The first was that of pure thought, the realm of "ideas," or "thought in general," while the second was its earthly realization in language, or in "the unmediated actuality of thought." ${ }^{16}$ Reality as it is developed mentally, according to Losev, always has "communicative directionality," because "language does not repeat the pure and abstract element [stikhiia] of thought, but gives it concrete substance, realizes it and interprets it anew, in order to become closer to reality in its original and, for thought, primary existence." ${ }^{17}$ The American linguist Sebastian Shaumyan has commented that "Losev's law of polysemy is the most important discovery since the 1930s, when the basic concepts and principles of the classical semiotic paradigm were formulated." 18

Nevertheless, Losev's main work of these decades was the writing of the monumental eight-volume Istoriia antichnoi estetiki (History of Classical Aesthetics, 1963-94), in which a thousand years of Classical thought is analyzed, from the birth of aesthetics and the aesthetic terminology of 
the Homeric era to early Christian neo-Platonism and the Gnostics. The books Estetika Vozrozhdeniia (The Aesthetics of the Renaissance, 1978) and Ellinisticheski-rimskaia estetika I-II vv. n.e. (Hellenic-Roman Aesthetics of the First and Second Centuries, 1979) are thematically related to this work. If we take into account his unfinished work of the 1960s, "Srednevekovaia filosofiia" ("Medieval Philosophy"), Losev's design for the recreation of an historical panorama of European aesthetics and philosophy, in all its fullness, becomes obvious.

The symbolic conclusion of Losev's life's work was his book on Solov'ev, the first on this philosopher to be written in the entire Soviet period. Losev considered Solov'ev to be his spiritual teacher: his extraordinary encyclopaedic interests are rooted in Solov'ev's concept of pan-unity. The book had a complicated fate: a shorter version, printed in 1983, was published but subject to a confiscation order, and the entire print run was exiled to remote regions of the north, central Asia, and the far east, ${ }^{19}$ while the full version, Vl. Solov'ev i ego vremia (V. Solovev and his Time) only came out after the author's death.

In 2004 the State Library of the History of Russian Philosophy and Culture was opened in Losev's house, in which he had lived for the last fifty of his ninety-five years, on the Old Arbat in Moscow. The "House of A. F. Losev" is a memorial not only to the philosopher himself, but to the whole of Russian philosophy, including the thought of those who took part in the Vekhi symposium. It is fitting that an international conference entitled "The Vekhi Symposium in the Context of Russian Culture" was held in the "House of A. F. Losev" to mark the centenary of Vekhi's publication. ${ }^{20}$

\section{Losev and the Vekhi Authors: Biographical Connections}

Losev is often referred to as the last representative of the Silver Age of Russian culture. However, there have still been no studies made of the personal connections between Losev and his older colleagues in philosophy. It is difficult to fill this gap in our knowledge, because Losev's entire personal archive, and his correspondence from the middle of the 1910s until the end of the 1920s, were lost upon his arrest in 1930. The main venue for meetings between Losev and the philosophers of the early 
twentieth century, including the Vekhi contributors, was the Vladimir Solov'ev Religious-Philosophical Society in Moscow. There Losev was able to exchange views with Nikolai Berdiaev, Sergei Bulgakov, S. N. Durylin, Ivanov, I. A. Il'in, G. A. Rachinskii, E. N. Trubetskoi, Frank, and Florenskii (Father Pavel was the priest who married Losev and V. M. Sokolova in 1922). ${ }^{21}$ Losev related how he was often present at meetings of the Religious-Philosophical Society, and how he used to receive notifications of and invitations to meetings. ${ }^{22} \mathrm{He}$ states that he went to a meeting of the Society for the first time at the house of Margarita Kirillovna Morozova to hear Ivanov give a paper entitled "On the Margins of Art," on 14 November 1913. ${ }^{23}$ "Grigorii Alekseevich Rachinskii presided at the meeting. ... The speaker, Ivanov, sat next to him, then Evgenii Trubetskoi, and Berdiaev was there too." ${ }^{24}$ It appears that the young Losev, who was in raptures over Ivanov's speech, was not as swayed by Berdiaev's contribution to the discussion: “Berdiaev endorsed Viacheslav Ivanov's aesthetics, but he said that one should make art accessible to a wide audience and to do that one had to write simply, although it is absurd to say such things to Ivanov: clearly he can't write like Pushkin." ${ }^{25}$ Nonetheless other contributions by Berdiaev had a lasting and "enormous impact" on him: "A brilliant orator. He had one flaw that he suffered from all his life, a facial tic ... a terrible tic: his face would regularly distort into a grimace and he would stick his tongue out. But this did not prevent him from speaking. He spoke beautifully" ${ }^{26}$ and "loved to speak. It was a basic need for him, such that on one occasion he remarked: I haven't spoken today yet! How can this be? He usually spoke with restraint, in a considered way. Not passionately, as he does in The Meaning of the Creative Act [Smysl tvorchestva, 1916]. Berdiaev is a writer-orator. He writes absolutely brilliantly. But his speech was calm, unprovocative, and accessible." ${ }^{27}$

Losev first encountered another Vekhi contributor, Bulgakov, a year earlier, on 21 September 1912, at the latter's defense of his doctoral dissertation Filosofiia khoziaistva (The Philosophy of Economy) at Moscow University. For Losev, Bulgakov was "a genuine scholar," "a theologian who is equally a philosopher. ${ }^{28}$ In the five intervening years before the closure of the Religious-Philosophical Society in the summer of 1918, Losev may have been present at papers given by Bulgakov on "Russian Tragedy," 
about Dostoevskii's novel Besy (The Devils, 1872) (2 February 1914), “The Sophianicity of the World” (17 January 1916), “The Conquered Conqueror (the fate of Leont'ev)" (13 November 1916), his contributions on the subjects of the new Russia (15 April 1917) and Vladimir Ern (19 May 1917, at an evening commemorating Ern at which Berdiaev also spoke), and the paper "At the Feast of the Gods (Contemporary Dialogues)" (3 June 1918). ${ }^{29}$ In 1918 Losev, Bulgakov, and Ivanov attempted to publish a religious-philosophical series called Dukhovnaia Rus' (Spiritual Rus', see the next section, below). Neither Bulgakov nor Losev could have predicted that in 1930 Bulgakov's son Fedor would be arrested in connection with the Losev affair, and that in the 1960s Fedor would invite Losev to pose for a sculpture. ${ }^{30}$

Losev did not restrict himself to the role of silent listener in the Religious-Philosophical Society. He presented a paper on "The Question of the Fundamental Unity of Plato's Dialogues Parmenides and Timaeus," which elicited responses from Rachinskii and Florenskii. ${ }^{31}$ When the Society ceased to exist, Losev began to attend meetings in Berdiaev's apartment and at his Free Academy of Spiritual Culture.

Of all the contributors to Vekhi, Losev enjoyed the closest relationship with Frank. Since his youth Losev had been a dedicated reader of the journal Russkaia mysl' (Russian Thought), where Frank was chief editor of the philosophy and literature sections, and of the journal Logos, in which Frank regularly published. ${ }^{32} \mathrm{He}$ would recall his special relationship with Frank all his life, and in the mid-1970s noted that "Frank valued me highly." ${ }^{\prime 3}$ And in 1930, in the notes to Essays on Classical Symbolism and Mythology, he relates how his research into Plato's use of the terms "eidos" and "idea" was discussed in various Moscow academic societies: in the Lopatin Philosophical Society in June 1921, in Berdiaev's Free Academy in April 1922, in the Moscow Psychological Society in June 1922, and also in the Institute of Scientific Philosophy; in this connection he recalls that Frank 'fully took on board my work on 'eidos' and 'idea' and told me personally that ' $[\mathrm{a}]$ new understanding of Platonism has been in the air in Europe for a long time now. You have discerned and articulated it."' ${ }^{34}$

As Losev recollected in 1975, Frank was the reason he ended up attending the sessions held at Berdiaev's home: "Frank and Il'in told me 
about them. So I went." 35 On 5 April 1922 the Free Academy, where Frank delivered a course of lectures entitled "Introduction to Philosophy," 36 reported on Losev's presentation of the paper "Greek Linguistic Ontology in Plato." Among the respondents were B. A. Griftsov, Rachinskii, P. S. Popov, B. P. Vysheslavtsev, and Frank. ${ }^{37}$

Frank participated in the discussion of Losev's work not only at the Free Academy and the Institute of Scientific Philosophy: we know that in the Lopatin Philosophical Society, too, when Losev gave a paper on Aristotle, Frank took part in the debate along with Griftsov, Rachinskii, and Vysheslavtsev. ${ }^{38}$ According to the notes to Music as an Object of Logic, Frank was also present at Losev's talk at the State Institute of Musical Science on 24 December 1921. ${ }^{39}$ In Music as an Object of Logic, Losev mentions exchanging views with Frank not only on the subject of his own definition of the number (in his view Frank's thinking about the number in Predmet znaniia [The Object of Knowledge, 1915] "sets out the meaning of my definition of the number in a more precise form"), ${ }^{40}$ but also on the coincidence of Frank's ideas with those of Plotinus. ${ }^{41}$

A common interest in Platonism and neo-Platonism informed their mutual attention to the philosophy of Nicholas of Cusa. Frank considered Cusa to be one of his greatest teachers (not for nothing did one of the outstanding philosophers of the Russian emigration, V. N. Il'in, devote an article to the relationship between Nicholas of Cusa and Frank). For his part, Losev wrote a book about Cusa in the 1920s, which was lost after his arrest, and in the 1930s he translated three of Cusa's treatises: "On the Notother," "On the Mind," and "On the Possible-actual." ${ }^{42}$ It appears he held conversations of some kind with Bulgakov about Cusa as well, or else how could he have known that Bulgakov possessed a sixteenth-century "copy of Nicholas of Cusa published in Lyons"? ${ }^{43}$

We can form an opinion about Frank's attitude to Losev from a review of his The Philosophy of the Name and The Ancient Cosmos and Modern Science which was published in the journal Put' (The Way) in 1928. When he was preparing his review, Frank well understood the consequences that praise for Losev in the press of the White emigration would have for the Soviet philosopher. In an unpublished letter from Frank to the journal's editor, Berdiaev, dated 8 November 1927 and accompanying his review of 
Losev's books, we find the following lines: "Dear Nikolai Aleksandrovich ... I have been cautious and have not said everything that should have been said, but have confined myself to allusions in order not to cause Losev trouble." ${ }^{44}$ Aware of the obligatory concessions to the Soviet censorship in Losev's books, Frank writes that "the isolated irritating passages in which the author pays tribute, as it were, to the ruling 'spirit of the age' ... are organically quite unrelated to the rest of the content of his ideas," and that "there is no need to dwell on these; the 'tribute' is clearly an unwilling one." ${ }^{35}$ For Frank what is important is that "with his books the author has undoubtedly joined the ranks of the foremost Russian philosophers and ... has borne witness to the fact that even inside Russia the spirit of true philosophical creativity is alive, the pathos of pure thought, directed towards the absolute: a pathos which itself is, in its turn, a witness to spiritual life and spiritual fire." 46

According to Frank, The Ancient Cosmos and Modern Science, which is devoted to the dialectics of being, represents a detailed analysis of just one of the aspects of The Philosophy of the Name, in which "the author's own philosophical system is set out." "Briefly and in popular language" summarising Losev's "infinitely complex and abstract construction," Frank conveys the essence of Losev's philosophical conception as follows:

For the author, the name, as the place where the "meaning" of human thought and the immanent "meaning" of the object world itself meet, is in its ultimate completion the expression of the essence of being itself. Everything in the world, including dead nature, is "meaning," and therefore the philosophy of nature and the philosophy of spirit unite in the philosophy of the "name" as the self-disclosure of meaning. The name in its completion is the "idea," capturing and expressing the "eidos," the essence of the object. The name acquires ultimate fullness and depth when it also embraces the precious "apophatic" layer of being: it then reveals itself as "myth," which is not an invention but, on the contrary, the ultimate plenitude, self-revelation, and self-understanding of reality. The philosophy of the name thus coincides with the dialectic of the selfunderstanding of being and by the same token with philosophy itself, for the "name," understood ontologically, is the highest pinnacle of being, reached through its immanent self-revelation. ${ }^{47}$

At the same time, Frank considers it essential to draw attention to the traditions whose development, continuation, or re-conceptualization 
are most apparent in The Philosophy of the Name. The first of these is Classical dialectics-Plato's Parmenides and the further development of its constructions in Plotinus and Proclus. The second is the phenomenology of Edmund Husserl, transformed by Losev, drawing on Plato and the neoPlatonists, "into a universal 'dialectics', which for him is identical with philosophy as such." The third comprises "the obvious points of contact with the ideas of Florenskii and his 'magic of the word." Fourth, "the many pages of The Philosophy of the Name in which categories dialectically give rise to one another are extraordinarily reminiscent of Hegel, and indeed in terms of difficulty, complexity, but at the same time subtlety in the working of abstract thought, there can hardly be many examples since Hegel's Phenomenology of Spirit of philosophical systems on a par with that of Losev." ${ }^{38}$

It is curious that Losev knew about this review by Frank, which had been published in Paris: the Foreword to his Dialectical Foundations of Mathematics, dated 29 April 1936, makes reference to it. ${ }^{49}$ It is likely that in the 1920s Losev was still able to maintain links with émigrés and to access émigré publications, something that was harshly punished by the Soviet authorities. ${ }^{50}$ We know that in 1923 he read Berdiaev's Filosofiia neravenstva (Philosophy of Inequality), which contained sharp criticism of the Soviet regime, and that Berdiaev's "inspired words" made a huge impression on him - such that in the 1970s he could quote from this work from memory: "What have you done to my country!"51 Thus it was no accident that in 1930, in the course of Losev's interrogation, he was reminded of his acquaintance with Berdiaev. It is not impossible that the link between Paris and Losev was the well-known botanist Professor V. V. Markovich (arrested in 1932 in connection with the affair of Leningrad's Aleksandr Nevskii Brotherhood), ${ }^{52}$ or the Dane M. M. Brensted, who appears in the memoirs of Lidiia Berdiaeva and who lived in Russia in the 1920s, but left for Paris in the year of Losev's arrest, subsequently collaborating on Berdiaev's journal The Way. ${ }^{53}$

Even in his old age Losev preserved a special piety in regard to the older philosophers with whom he had had the good fortune to engage. "I have retained not just a bright, but a dazzling impression of them all," ${ }^{54}$ he confessed, not attempting to count himself their equal. "As people, they were 
real giants of their kind, so that I would hardly dare to shake their hand, just say 'how do you do.' At most I had some insignificant conversations with just one or two of them. ${ }^{55}$ In a documentary film made at the end of his life, Losev speaks in the same spirit:

I was a student just starting out, but these were very important people. All those Bulgakovs, Berdiaevs, and Trubetskois, they were already giant figures, so to speak. I even used to greet them formally and they would shake me by the hand, but I didn't really manage to get close to any of them.... And anyway, the revolution was on its way: I graduated from university in 1915, and in 1917-revolution! So just when I was rather more grown-up and could make my presence felt more strongly and get properly close to them, it was all broken off by events, mechanically ... only Frank, perhaps, he was somehow enthused by my research on Platonism and understood me more sensitively and deeply. But the rest were too far above me, at too far a remove from this young lad who had just shown up in Moscow and didn't know anything or anyone, and anyway what contribution could he bring and what could he say. ${ }^{56}$

However, the story of Losev's intellectual and spiritual opposition (in particular his collaboration on the Spiritual Rus' series, described below) is testament to the fact that in his oral reminiscences, whether on purpose or not, he downplayed the degree of his real and actual proximity to the Vekhi authors.

\section{Losev's Opposition to the Revolutionary "Cause" ( Delo")}

Several key stages in the history of Losev's opposition to the revolutionary "cause" by means of the "word" can be distinguished, and they serve to illuminate his relationship to the Vekhi tradition.

The first stage that we know about was a project to publish a series of books devoted to Russian national identity under the general title Spiritual $R u s^{\prime} .{ }^{57}$ The plan for the project was conceived by Ivanov, Bulgakov (by now Father Sergii Bulgakov), and Losev in the spring of 1918: Losev was to be general editor. Losev informed the publisher, M. Sabashnikov, that the series "exclude[d] the remotest possibility of any party viewpoint," but he made no secret of the fact that the authors' views were anti-Marxist, although "the approach [was always to be] that of a free, non-confessional religious 
consciousness." ${ }^{58}$ The series was to include works by Berdiaev, Bulgakov, the poet Georgii Chulkov, Sergei Durylin, secretary of the Vladimir Solov'ev Religious-Philosophical Society, the critic and publicist A. S. GlinkaVolzhskii, Ivanov, Evgenii Trubetskoi, and Losev himself. The project was never realized, but analysis of the proposal indicates that Berdiaev's essay "Ghosts of the Russian Revolution (Gogol, Dostoevskii, Tolstoi)," along with the articles by Bulgakov and Ivanov that were similarly included in Struve's symposium Iz glubiny (Out of the Depths), were originally intended for Losev's Spiritual Rus' also. The chronology of the preparation of both publications is the same, running from March to August 1918; the parallelism of their ideas is quite evident as well. Spiritual Rus', like Out of the Depths, was intended as a sui generis continuation of Vekhi.

In the first half of 1918, Losev published his work in the newspaper Zhizn' (Life), ${ }^{59}$ which was opposed to the Soviet authorities from an anarchist standpoint, that is, from a standpoint exactly opposite to that of Vekhi and Out of the Depths-hence the polemical attacks on the newspaper by the weekly Nakanune (On the Eve), which published the work of the Vekhi authors Berdiaev, Bulgakov, and Struve. The appearance of Losev in such a publication may seem strange, but in the context of a rapidly contracting space for free discourse uncontrolled by the Bolshevik censorship, the newspaper attracted people of various political persuasions, including well-known writers like Anna Akhmatova, Belyi, Aleksandr Blok, and Osip Mandel'shtam.

Of the three articles published by Losev in Life, "The Crisis of the Private Secondary School" and the review article "Russian Philosophical Literature in 1917-18" are of the most interest to us. ${ }^{60}$ In the first the author describes, with emotional restraint and relying only on facts and figures, the catastrophic situation in private schools, the last "islets" not to be exposed to the pernicious influence of the new ideology. The article on Russian philosophy, for its part, only at first sight appears removed from social problems and the debate about the Russian intelligentsia and revolution that was conducted in Vekhi in 1909. It seems that the twenty-four-year-old Losev deemed the position of his older colleagues from Spiritual Rus' to be too passive. Losev was convinced that "from of old Russian philosophy, which is in essence social and frequently mystical at base, has always 
reacted strongly to social and political phenomena, describing them from the point of view of its more profound conception of the world." ${ }^{61}$ As he himself put it, Losev was looking to philosophy for a spiritual "weapon for the fight," 62 and he was unhappy that "despite the horrifying course of events Russian philosophy is silent, and we do not know what it has to say about everything that is happening." ${ }^{3}$ This is why he writes with a certain reticence about the works of the "Slavophiles," Bulgakov's Svet nevechernii (The Unfading Light, 1917) and Tikhie dumy (Quiet Thoughts, 1918), Ivanov's Rodnoe i vselenskoe (The Native and the Universal, 1917), and Evgenii Trubetskoi's Metafizicheskie predpolozheniia poznaniia. Opyt preodoleniia Kanta $i$ kantianstva (The Metaphysical Presuppositions of Knowledge. An Essay in Overcoming Kant and Kantianism, 1917). Thus, after paying tribute to Bulgakov's "sincere, profoundly Orthodox mysticism," "the religion of the Russian Christ that is the final and longed-for end of Bulgakov's entire work," he concludes that there is "little that is new and fiery" in The Unfading Light. ${ }^{64}$

Losev's intellectual affinities made him closer to the "western" wing of Russian thinkers at the time, among whom Losev classed Gershenzon (Mudrost' Pushkina [The Wisdom of Pushkin, 1917], Troistvennyi obraz sovershenstva [The Trinitarian Image of Perfection, 1918]), Frank (Dusha cheloveka. Opyt vvedeniia v filosofskuiu psikhologiiu [The Soul of Man: Introduction to Philosophical Psychology, 1917]), Il'in (Filosofiia Gegelia kak uchenie o konkretnosti Boga i cheloveka [The Philosophy of Hegel as a Doctrine on the Concreteness of God and Man, 1918]), and P. I. Novgorodtsev (Ob obshchestvennom ideale [On the Social Ideal, 1917]). Losev welcomed Il'in's "ardent affirmation of eternal truths" and Novgorodtsev's "objective critique of Marxism." He warmly recommended Frank's book as "a superb weapon in the fight against the outmoded and crude conventions of sensualism and materialism," ${ }^{65}$ while in Gershenzon's Trinitarian Image of Perfection he valued a "precise and clear ... sense of the vital antinomies of which everything consists," "a feeling for the contradictions and lamentable chaos of life," which "are also an essential stage on the way to ultimate affirmations." 66

The second landmark in Losev's opposition to the revolutionary "cause" is his participation in the Swiss collection Russland (Russia), in 
which his article "Russian Philosophy" was published. ${ }^{67}$ According to the table of contents, the first part of Russia was to include a second article by Losev, "Die Ideologie der orthodox-russischen Religion" ("The Ideology of Russian Orthodoxy"). This article was listed as appearing in Russia but for unknown reasons it never did so. Losev apparently intended to submit it, since an essay in German, "Die Onomatodoxie" ("Onomatodoxy"), survives, devoted to "one of the oldest and most typical trends in the Orthodox east," the name-worship that attracted numerous apologists among Russian religious thinkers of the early twentieth century. ${ }^{68}$

Russia was edited by Vera Erismann-Stepanova, Theodor Erismann, and Jean Matthieu, and was published in Zürich in 1919. ${ }^{69}$ Matthieu was an active Swiss social democrat, while Erismann-Stepanova was a graduate in philosophy from the University of Zürich who was married to the psychologist Theodor Erismann. ${ }^{70}$ Family tradition has it that the initiative for Russia came from the Erismanns, ${ }^{71}$ but be that as it may, it seems that the ideological platform was the idea of Erismann-Stepanova's brother-in-law, the well-known historian Sergei Mel'gunov, who was exiled from Russia in 1922 on the famous "philosophical steamship." Mel'gunov's atheistic, liberal-populist position, which informed his attacks on Vekhi in 1909,72 changed to a certain extent when the Bolsheviks came to power. Mel'gunov started to look for allies in various political circles, and this brought him to the Soiuz vozrozhdeniia Rossii (Union for the Revival of Russia, established in 1918), which aimed to restore Russian statehood. It was probably only for tactical reasons that Mel'gunov's name was not included in the list of editors of Russia. The collection contains an article by him on church and state in Russia, and another by his wife, Erismann-Stepanova's sister, Praskov'ia, and the majority of Russia's other contributors (the publicist Ivan Belokonskii, the pedagogue Nikolai Rumiantsev, the historian Konstantin Sivkov, and the folklorist Boris Sokolov) had actively published their works in Mel'gunov's co-operative publishing house, Zadruga. It is likely that the project aimed to provide the western reader with detailed information about Russia and its culture, and that aim was in conformity with the ideas of Mel'gunov as a member of the Union for the Revival of Russia.

In this context one thing remains unclear, and that is how Losev's article "Russian Philosophy" came to be included in this publication. ${ }^{73}$ There is 
no evidence that Losev and Mel'gunov were acquainted, but we know that Losev became a member of Zadruga at some point between 1918 and 15 May 1919: ${ }^{74}$ his name appears in the membership list until 15 May 1919, ${ }^{75}$ and in 1919 he considered publishing his Genesis of Greek Tragedy with Zadruga. Several hypotheses can be advanced. The most persuasive is that Losev's friend from university days, Pavel Popov, acted as an intermediary between Losev and Mel'gunov between 1917 and 1919. Popov had become acquainted with Mel'gunov in the late 1910s, and was an active member of Zadruga.

Like the review of philosophical literature in Life, Losev's article for Russia is only superficially unrelated to the problems debated in Vekhi. For a start, albeit unsurprisingly, Losev includes Berdiaev, Bulgakov, and Frank in his list of the representatives of contemporary Russian philosophy. $\mathrm{He}$ offers a brief description of Berdiaev's The Meaning of the Creative Act and Bulgakov's The Unfading Light. He also quotes copiously from Berdiaev's book on Khomiakov because, as he himself explains, Berdiaev "is one of the most significant representatives of contemporary Russian philosophy," and it is evident from his book that "in our time Russian philosophy has become aware of its own essence, and that, as a rule, it is true to this essence in only setting itself the tasks that have always been associated with genuine Russian philosophy."76 Losev believes that, beginning with Solov'ev, "a new Russian apocalyptic conception of the world"77 had come into being; it is therefore unsurprising that Berdiaev and Bulgakov seem to him to be "Slavophiles with the addition of apocalyptic mysticism." ${ }^{\text {. }}$ Additionally (and in the context of Vekhi this is particularly noteworthy), Losev underlines the publicistic principle present in Russian philosophy. $\mathrm{He}$ states that Russian philosophy, with its characteristic "mystical-ontological realism," 79 has always been "intricately connected with real life, and for this reason often appears in polemical and publicistic guise, drawing its vitality from the general spirit of the age, with all its positive and negative aspects, with all its joys and sufferings, with all its order and chaos." ${ }^{80}$

Losev did not choose to write about the history of Russian thought only out of a desire to inform his western readership about a world with which it was unfamiliar. He highlights the philosophical character of Russian literature, the philosophy of the Slavophiles, and above all the philosophy of 
Solov'ev, that is, the creative endeavors of precisely those Russian thinkers "the Russian intelligentsia does not want to know," according to Berdiaev's essay for Vekhi, "Filosofskaia istina i intelligentskaia pravda" ("Philosophical Verity and Intelligentsia Truth"). Losev develops Berdiaev's thinking on the "concrete idealism" or "ontological realism" of Russian philosophy, and on its religious foundations as reflected in the striving for a "synthesis of knowledge and faith." At the same time, Losev's assertion that "Russian philosophy has never dealt with anything other than the soul, the person, and inner asceticism" ${ }^{81}$ also invites comparison with Bulgakov's essay for Vekhi, "Geroizm i podvizhnichestvo" ("Heroism and Asceticism"), in which the spiritual act and Christian asceticism are opposed to the intelligentsia's heroism and anthropotheism. In his texts from 1918, Losev agrees with Bulgakov on the need to form a "national self-consciousness" on "religiouscultural foundations."

Although Vekhi is neither directly quoted nor mentioned in Losev's article, one can nevertheless see here a continuation of the conversation begun in Vekhi by Berdiaev, who thought that "the purifying fire of philosophy" was to play a significant role in the radical reformation of the intelligentsia's consciousness. Subsequently, Losev would make further discreet reference to Berdiaev's Vekhi essay. For example, in the late 1930s allusions to this essay appear in Losev's novel Vstrecha (The Meeting), which is the closest of his works to the set of problems discussed in Vekhi. Meanwhile, Berdiaev's reference to a special "proletarian class mysticism" is recalled in The Philosophy of the Name and The Dialectics of Myth, in which Losev writes about the mysticism of materialists, the communist and proletarian mythology. A telling example is the grotesquely ironic apology for "a world without end or limit, without form or bounds," a blind and dead material world that true materialists fanatically believe in: "We have our own mythology, and we love it, cherish it, we have spilled and will again spill our living and warm blood for it." ${ }^{\prime 2}$

Whatever the interest-considerable as it is-of Losev's attempts in the years 1917-19 to express his social-philosophical position, it was The Dialectics of Myth (1930), the last anti-Marxist book to be published in the Soviet Union, that marked the culmination of his intellectual and spiritual opposition to the Soviet order. ${ }^{83}$ This work is not about ancient myths. 
It is about a different kind of mythology: the ideas of the public sphere that possess individuals as well as entire social groups. The Dialectics of Myth is at once a religious-philosophical treatise exploring the dialectics of the mythology of the Absolute and a sui generis sociological study of the psychology of mass thinking, an attempt to define the basic ideological units that pre-determine the behavior of specific social groups or whole nations.

The polemical, almost publicistic, tone that, unusually for a work of philosophy, permeates Losev's text, is confirmation that this work continues the tradition of social-philosophical (typically journal) writing of the Vekhi authors, and indeed of Vekhi itself, and, in a broader sense, of a classical Russian philosophy that (as Losev himself declared in "Russian Philosophy") is notable for its vitality, its involvement in real social life, and its interest in pre-logical, mythological thinking. It is not without reason that The Dialectics of Myth developed many of the themes of Vekhi: atheism as a peculiar religious faith, the idolization of science and progress by the intelligentsia, and the rejection of positivism and rationalism in philosophy. Echoing/repeating Frank's article "The Ethics of Nihilism," ${ }^{4}$ Losev stresses the real spiritual and religious foundations of social and political events by demonstrating how spiritual nihilism-the negation of both the Absolute and the mythology of the Absolute-transform man into nothing and plunge him into a spiritual and social hell where various relative mythologies, including Marxism, reign:

From the point of view of Communist mythology, not only [is it the case that] "a specter wanders in Europe, the specter of Communism" ([as stated at] the beginning of the Communist Manifesto), but also [that]"the vermin of counterrevolution are swarming," "the jackals of imperialism are howling," "the hydra of the bourgeoisie is baring its teeth," and "the jaws of financial sharks are gaping." Here we also find scurrying about such figures as "bandits in tail-coats," "monocled brigands," "crowned blood-letters," "cannibals in mitres," and "cassocked jaw-shatterers." In addition, everywhere there are "dark forces," "gloomy reaction," "the black army of obscurantists"; and in this darkness there is "the red dawn" of "global fire," "the red flag" of rebellion. What a picture! And they say there is no mythology here. ${ }^{85}$ 
The opposition Losev constructs between proponents of the mythology of the Absolute and adherents of relativist mythologies such as socialism in many aspects mirrors the opposition in Vekhi between two socialphilosophical types: the opponents and the advocates of revolution.

Contemporary readers may share the view of some that Losev's attacks on socialism and communism get lost in the theoretical analysis of the nature of myth and mythological thinking, but even these sporadic passages were enough to have their author sent to one of the forced labor camps organized for the construction of the White Sea-Baltic canal, and to have him condemned as a class enemy at the 16th Party Congress. After his release his works were not published until after Stalin's death, but his intellectual and spiritual opposition to the regime did not cease. In the 1930s and 1940s, Losev's opposition to Soviet reality is expressed in his literary works, in which one can also find allusions to Vekhi and the problems addressed therein. In Meeting, mentioned above, the problem treated is that of the intelligentsia and revolution. In the story "Iz razgovorov na Belomoro-Baltiiskom kanale" ("From Talks at the White Sea-Baltic Canal"), Losev addresses the question of production under socialism that so greatly troubled the Vekhi authors, above all Frank. The main subject of debate for the interlocutors in the story is the question of the correct attitude to technology. For the author, this question is closely related to the problem of civilization as the last stage of human history, when the human spirit is subjugated to the spirit of the thing, the machine. Such a "neo-Luddite" orientation was typical for the turn of the twentieth century, when "it was as if literature became the site of a pitched battle between the 'mechanizers' and the 'antimechanizers," as reflected in the novels of H. G. Wells and the dystopias of E. M. Forster or Aldous Huxley. In their "brave new world," power has also been usurped by a new and humanly improved "Lord our Ford, or Freud" (Huxley). Man himself prays to the machine because the Bible has long since been replaced by the "Book of the Machine" (Forster). ${ }^{86}$ At the same time this idea of Losev's is in complete agreement with the general outlook of Russian religious philosophical thought. Thus, for Berdiaev, socialism is "civilization, but not culture" because "culture is organic" while "civilization is mechanical." 
In a world in which animated being has been replaced by the inanimate, God and the idea of the Absolute are squeezed out by matter, and the logic of the absurd comes into play such that, as the central protagonist of Meeting, Nikolai Vershinin, says, "they want to base morality and self-sacrifice for the sake of society on the natural sciences, on biology," or when a person who has been deprived of his personhood and soul has it explained to him that "they say you are descended from the apes. Therefore you should love one another." ${ }^{\prime 8}$ Vershinin's words are a veiled quotation from Berdiaev's Vekhi article: "Vladimir Solov'ev very wittily observed that the Russian intelligentsia always reasons from the same syllogism: man is descended from the apes, therefore we ought to love one another. The intelligentsia perceived scientific positivism wholly in terms of this syllogism; positivism was merely an instrument for affirming the reign of social justice and for utterly destroying those metaphysical and religious ideas which, the intelligentsia dogmatically assumed, support the reign of evil" (21). Only in this context can the direction of Losev's thinking be properly understood. Losev is persuaded that the triumph of materialism and the extirpation of metaphysical and religious ideas distort morality and transform man into an ape and the world into a prison. As he says through his mouthpiece Vershinin, all his abstract talk about philosophy or music is but "an analysis of the Russian revolution." ${ }^{89}$

Beginning in the mid-1950s, Losev worked on his History of Classical Aesthetics in eight volumes. His withdrawal to the history of philosophy was a forced step, but it gave him the opportunity to realize at least partially his plan of the 1920s to create a general typology of cultures that presupposed their present condition. By plunging into antiquity, Losev seemed to abandon the burning social problems of Vekhi, but his mood was quite different. Allegorically, in Aesopian language, he continued to develop ideas similar to those of the Vekhi authors. For example, in 1985 the Party newspaper Pravda published a conversation with Losev entitled "Derzanie dukha" ("The Daring of the Spirit")..$^{90}$ Is it an accident that the title reminds us of Berdiaev's words in Vekhi about "the love of truth and the daring of thought [derznovenie mysli]" that are being extinguished by the reigning demagogy? It is unlikely. This is confirmed by Losev's argument, expressed during the interview, that as a counterweight to an 
irrational technologism aimed at the destruction of the human person and humanity there should be a correct worldview, "a secret or open striving for freedom," ${ }^{11}$ and that there was a need to educate young people in "love for the profundity and beauty of thought for its own sake." ${ }^{22}$ It is not without reason that Losev makes the reservation that he may be considered "a bad idealist for preaching a quiet, conciliatory and sober way of thinking," ${ }^{93}$ given that his words are a paraphrase of Gershenzon's argumentation about "creative self-consciousness."

\section{CONCLUSION}

Of all the participants in Vekhi, three figures-Berdiaev, Bulgakov, and Frank-attracted Losev's attention throughout his life. In Gershenzon he saw "a profound critic" with a "beautiful style," but toward the end of his life he was rather critical of his philosophy in general..$^{94}$ Losev's special relationship with Frank has already been discussed in detail. As far as Berdiaev and Bulgakov are concerned, there are many positive references to them in Losev's work. In the 1970s Losev had in his field of vision Bulgakov's books The Unfading Light (1917), Lestvitsa Iakovlia (Jacob's Ladder, 1929), and Nevesta Agntsa (Bride of the Lamb, 1945), and Berdiaev's The Meaning of the Creative Act, Opyt opravdaniia cheloveka (Essay in Religious Anthropology, 1916), O naznachenii cheloveka (On the Destiny of Man, 1931), ${ }^{95}$ Samopoznanie (Self-Knowledge, 1949) ${ }^{96}$ and Ekzistentsial'naia dialektika chelovecheskogo $i$ bozhestvennogo (The Dialectic of the Human and the Divine in Existentialism, 1952). If Bulgakov's books delighted him with their marvelous titles, ${ }^{97}$ Berdiaev's did so by their style: "Sometimes in Berdiaev every phrase is an aphorism. 'The personality is the sacrament of one, marriage is the sacrament of two, the church is the sacrament of three.' Or, 'Two types of Satanism, fascism and communism.' But this is not politics, it is a meticulously worked out philosophy." ${ }^{98}$ To Losev, it is important that Bulgakov, and Berdiaev too, are "Solov'evians," although "touched by the twentieth century." ${ }^{9}$ Not for nothing does he devote a special paragraph to describing Bulgakov's relationship to Solov'ev's philosophy in his book on the latter. ${ }^{100}$ In the documentary film "Losev" he speaks with no less enthusiasm about Berdiaev's philosophy, and calls 
him "an apostle of freedom." According to Losev, Berdiaev "senses the divinity of his freedom like Angelus Silesius, who said: 'Without me God could not make the tiniest movement."' ${ }^{101}$ It is interesting that in one private conversation Losev aligned himself precisely with Berdiaev: "Like Berdiaev I call myself a child of freedom." ${ }^{102}$ All the more, then, did he suffer from not being able to work openly in conditions of unfreedom, not being able to study his favourite thinkers and own their books: "Once I saw that someone was selling six or seven of Berdiaev's works for fifty rubles. But I was afraid of political provocation. Moscow would find out immediately who that man sold his books to." ${ }^{103} \mathrm{He}$ recommends reading Berdiaev: "Even if you don't share all his views, it is always useful to commune with a genius," but at the same time acknowledges that this is dangerous since "it's dangerous not even to read, but simply to keep the books. You get persecuted for that [...] They lock you up, there's been the trial of Daniel', Siniavskii, Ginzburg."104 It seemed demeaning to him to study his favorite philosophers in secret: "No, I don't like it when you have to hide. I say what I think; I'd repeat it in front of an audience of two hundred. Let everyone see what Losev thinks. I like to do things openly. But to study Berdiaev by reading him in snatches at night-that's not interesting. You have to study seriously so as to think things through, you have to become absorbed." ${ }^{105}$

Of course, seventy years of the Soviet system trained Losev to write in Aesopian style. But as soon as perestroika began in the Soviet Union, the philosopher began to speak openly about Vekhi. This is evident in the documentary filmed in 1987, toward the end of Losev's life, by V. Kosakovskii. "Today Vekhi is deemed to be a dreadful book, you can't read or own or discuss it," he declares, and admits at the same time that " $[\mathrm{w}]$ hen I read it I was excited by its profound thought. Very profound thought! They saw that the revolution suppressed the person too much. That's why the cry went up, 'Where is man?' Well, production-production is good. Progress, the public. ... But where is man? He isn't there."106

The philosopher had to spend the major part of his life in a depersonalized, dehumanized society, suffer many catastrophes, and make various sacrifices, but inwardly he remained faithful to the social-philosophical strategy of resisting evil with the word and with creative activity in the field 
of culture. In the days of his youth this strategy had also guided his older colleagues, the Vekhi authors, in their philosophical endeavor.

NOTES

1 This article was written as part of the project RGNF $11-03-00408 \mathrm{a}$.

2 Vekhi. Iz glubiny, ed. A. A. Iakovlev (Moscow: Pravda, 1991). Page references to this edition appear in parentheses in the text.

3 See A. Haardt, Husserl in Russland: Phänomenologie der Sprache und Kunst bei G. Spet und Aleksej Losev (Munich: Wilhelm Fink Verlag, 1993); The Life and Thought of Aleksei Losev, special edition, Russian Studies in Philosophy 35: 1 (1996); A. Jubara, Die Philosophie des Mythos von Aleksej Losev im Kontext "Russischen Philosophie" (Wiesbaden: Harrassowitz Verlag, 2000); The Dialectic in A. F. Losev's Thought, special edition, Russian Studies in Philosophy 40: 3 (2002); Aleksej Fedorovich Losev: Philosophy and the Human Sciences, ed. Robert Bird, Studies in East European Thought 56: 2-3 (2004); H. Kuße, Metadiskursive Argumentation. Linguistische Untersuchungen zum russischen Diskurs von Lomonosov bis Losev (Munich: Otto Sagner, 2004); A. F. Losev and Twentieth-Century Human Sciences, Russian Studies in Philosophy 44: 1 (summer 2005); A. A. Takho-Godi, Losev, 2nd ed. (Moscow: Molodaia gvardiia, 2007) (“Zhizn' zamechatel'nykh liudei” series); M. Dennes, ed., L'Euvre d'Alekseï Losev dans le contexte de la culture européenne, Slavica Occitania 31 (2010).

4 S. L. Frank, “Novaia russkaia filosofskaia sistema," Put' 9 (1928).

5 The reference is to the police investigation of Andrei Belyi's wife and was given to me by M. L. Spivak.

6 The Dialectics of Myth has been translated into Bulgarian, Czech, English, German, Japanese, Serbian, and Spanish. The most reliable edition of Losev's book in Russian is: A.F. Losev, Dialektika mifa. Dopolnenie k Diakektike mifa (Moscow, 2001), Filosofskoe nasledie series, vol. 130). The English edition is A. F. Losev, The Dialectics of Myth, trans. V. Marchenkov (London: Routledge, 2003).

7 A similar idea for the second part of The Dialectics of Myth, partly lost as a consequence of his arrest, is a further argument in favor of the idea that Losev was one of the prototypes for the central protagonist of Mikhail Bulgakov's novel of the 1930s, Master i Margarita (The Master and Margarita), the "thrice romantic" master, with his idea to write a novel-in the Soviet period-about Christ and Pontius Pilate. See V. P. Troitskii, "Chernaia shapockha mastera," in V. P. Troitskii, Razyskaniia o zhizni i tvorchestve A. F. Loseva (Moscow: Agraf, 2007), 87-105. 
8 Unpublished fragment of Losev's work on Nicholas of Cusa and ancient-medieval dialectics.

9 Nathalie Duddington, "Philosophy in Russia," Journal of Philosophical Studies 6: 22 (1931): 226.

10 A. F. Losev and V. M. Loseva, "Radost' na veki”: Perepiska lagernykh vremen (Moscow: Russkii put', 2005), 57.

11 Unpublished commentary on Nicholas of Cusa's "De non aliud," composed in the 1930s.

12 A. F. Losev, Mif. Chislo. Sushchnost' (Moscow: Mysl', 1994), 334.

13 Ibid., 352.

14 Losev's essays on mathematics are collected in A. F. Losev, Khaos i struktura (Moscow: Mysl', 1997).

15 A. F. Losev, "Ia soslan v XX vek ..." (Moscow: Vremia, 2002). On Losev's literary prose, see E. W. Clowes, Fiction's Overcoat. Russian Literary Culture and the Question of Philosophy (Ithaca, NY: Cornell University Press, 2004), my book about Losev as a writer Khudozhestvennyi mir prozy A. F. Loseva (Moscow: Bolshaia rossiiskaia entsiklopediia, 2007), and my article "Alexey Losev's Philosophical Novel 'The Woman Thinker' and the Problem of the Eternal Feminine," Transcultural Studies: A Series in Interdisciplinary Research. Special Issue on Sophia Across Culture: From the Old Testament to Postmodernity, vol. 4 (2008): 131-39.

16 A. F. Losev, Iazykovaia struktura (Moscow: MGPI, 1983), 150.

17 Ibid., 148.

18 S. Shaumyan, "Dialekticheskie idei A. F. Loseva v lingvistike," in Obraz mira-struktura i tseloe (Moscow: Logos, 1999), 376.

19 See A. A. Takho-Godi, "K 20-letiiu vykhoda knigi A. F. Loseva Vl. Solov'ev v izdatel'stve Mysl': Delo o knige A. F. Loseva Vl. Solovev," in Vladimir Solovev i kul'tura Serebriannogo veka: K 150-letiiu Vl. Soloveva i 110-letiiu A. F. Loseva (Moscow: Nauka, 2007).

20 See A. A. Takho-Godi and E. A. Takho-Godi, eds., Sbornik "Vekhi" v kontekste russkoi kul'tury (Moscow: Nauka, 2007).

21 See my article "Zum gegenseitigen Verhältnis von A. F. Losev und S. L. Frank," in Kultur als Dialog und Meinung. Beiträge zu Fedor A. Stepun und Semen L. Frank, in Specimina philologiae slavicae, ed. H. Kuße, Bd. 153 (Munich: Verlag Otto Sagner, 2008), 219-37.

22 V. V. Bibikhin, Aleksei Fedorovich Losev. Sergei Sergeevich Averintsev (Moscow: Institut filosofii, teologii i istorii sv. Fomy, 2004), 225.

23 A. F. Losev, "Iz poslednikh vospominanii o Viacheslave Ivanove," in Eskhil. Tragedii: V perevode Viacheslava Ivanova (Moscow: Nauka, 1989), 464.

24 Bibikhin, Aleksei Fedorovich Losev, 242. 
25 Ibid.

26 Ibid., 29.

27 Ibid., 242-43.

28 Ibid., 161.

29 See "Moskovskoe religiozno-filosofskoe obshchestvo pamiati Vl. Solov'eva: Khronika russkoi dukhovnoi zhizni," ed. and intro. O. T. Ermishin, Literaturovedcheskii zhurnal 28 (2011): 711.

30 Takho-Godi, Losev, 158, 244.

31 A. F. Losev, "V poiskakh smysla," Voprosy literatury 10 (1985): 212. The interview was conducted by Viktor Erofeev.

32 A. A. Takho-Godi and V. P. Troitskii, eds., Aleksei Fiodorovich Losev. Iz tvorcheskogo naslediia. Sovremenniki o myslitele (Moscow: Russkii mir, 2007), 711.

33 Bibikhin, Aleksei Fedorovich Losev, 242.

34 A. F. Losev, Ocherki antichnogo simvolizma i mifologii (Moscow: Mysl', 1993), 698.

35 Bibikhin, Aleksei Fedorovich Losev, 243.

36 S. M. Polovinkin, "Vol'naia akademiia dukhovnoi kul'tury," Pravoslavnaia entsiklopediia (Moscow: Tserkovno-nauchnyi tsentr "Pravoslavnaia entsiklopediia," 2005), vol. 9, 284-86.

37 Takho-Godi and Troitskii, Iz tvorcheskogo naslediia, 711.

38 A. A. Takho-Godi, E. A. Takho-Godi, V. P. Troitskii, A. F. Losev-filosof i pisatel' (Moscow: Nauka, 2003), 24.

39 A. F. Losev, Forma. Stil'. Vyrazhenie (Moscow: Mysl', 1995), 586.

40 Ibid., 594.

41 Ibid.

42 E. Takho-Godi, "Nicolaus Cusanus in the perception of A.F. Losev," in Nicolaus Cusanus: ein bewundernswerter historischer Brennpunkt: Philosophische Tradition und wissenschaftliche Rezeption, ed. K. Reinhardt and H. Schwaetzer with O. Dushin (Regensburg, 2008), 255-79.

43 Bibikhin, Aleksei Fedorovich Losev, 161.

44 Related by A. A. Gaponenkov.

45 Frank, "Novaia russkaia religioznaia sistema," 90.

46 Ibid.

47 Ibid.

48 Ibid., 89.

49 A. F. Losev, Khaos i struktura, 11. 
50 For example, in 1928-29 members of the religious-philosophical circle Voskresenie were accused of reading and distributing White émigré publications. See Zvezda 11 (2006).

51 Bibikhin, Aleksei Fedorovich Losev, 245, 247.

52 See: www.sobornoedelo.ru/book.php? mode=get_glava\&glavaID=1107.

53 A. A. Takho-Godi, Losev, 150-51.

54 Bibikhin, Aleksei Fedorovich Losev, 245. Losev is here referring specifically to Berdiaev and Stepun.

55 Ibid., 225.

56 The documentary "Losev" was filmed by V. Kosakovskii in the last two years of Losev's life. The transcription is the author's.

57 The history of the planned series Spiritual Rus' is expounded in detail in my book Velikie i bezvestnye. Ocherki po russkoi literature i kul'ture XIX-XX vekov (St. Petersburg: Nestor-Istoriia, 2008), 425-42.

58 Ibid., 434.

59 For a detailed discussion of Losev's participation in Life, see Takho-Godi, Velikie i bezvestnye, 443-92.

60 All three texts are reprinted in Takho-Godi and Takho-Godi, Sbornik "Vekhi" $v$ kontekste russkoi kultury, 403-09. The article "Russian Philosophical Literature in 1917-18" is reprinted in Takho-Godi, Velikie i bezvestnye, 493-96.

61 E. A. Takho-Godi, Velikie i bezvestnye, 493.

62 Ibid., 495.

63 Ibid., 493.

64 Ibid.

65 Ibid., 495.

66 Ibid., 496.

67 For further detail on the history of this publication, see E. A. Takho-Godi, "A. F. Losev i sbornik Russland (1919): fakty i gipotezy," in Ot Kibirova do Pushkina: Sbornik v chest' 60-letiia N. A. Bogomolova (Moscow: Novoe literaturnoe obozrenie, 2011), 581-98.

68 A. F. Losev, Forma. Stil'. Vyrazhenie (Moscow: Mysl', 1995), 773-79.

69 A. F. Losev, "Die russische Philosophie," in Russland, I Teil: Geistesleben, Kunst, Philosophie, Literatur, II Teil: Politischer Bau, Soziale Bewegungen und gesellschaftlisches Leben, ed. V. Erismann-Stepanowa, Th. Erismann, and J. Matthieu (Zürich: Druck und Verlag s Art. Institut Orell Füssli, 1919), 79-109. Reprinted in USA by Nabu Press, spring 2010.

70 Theodor Erismann was the son of the Swiss doctor Friedrich (Fedor) Erismann, the founder of social hygiene as a branch of Russian medicine, and his second wife Sophie Hass, who held a doctorate in medicine from Bern University. 
71 This was the view of their daughter when asked about the collection by Magnus Ljunggren, a professor of Gothenburg University and friend of the family, in the summer of 2009 (when she was 90 years old). There are, however, reasons to doubt that this tradition is accurate.

72 See V. V. Sapov, ed., Vekhi: pro et contra. Antologiia (St. Petersburg: Russkii Khristianskii gumanitarnyi institut, 1998), 69, 774.

73 Losev, "Die russische Philosophie," 79-109.

74 See O kooperativnom tovarishchestve pechatnogo i izdatel'skogo dela 'Zadruga' (Doklad obshchemu sobraniiu chlenov 'Zadrugi'): 1912-1919 (Kharkov, Moscow, Petrograd, 1919), 25.

75 Ibid., 7-13.

76 A. F. Losev, "Russkaia filosofiia," in A. F. Losev, Strast' $k$ dialektike (Moscow: Sovetskii pisatel', 1990), 72.

77 Ibid., 91.

78 Ibid., 98.

79 Ibid., 77.

80 Ibid., 74.

81 Ibid., 90.

82 A. F. Losev, Filosofiia imeni, in A. F. Losev, Bytie. Imia. Kosmos (Moscow: Mysl', 1993), 773.

83 On Losev and his The Dialectics of Myth, see Philip T. Grier, "Adventures in Dialectic and Intuition: Shpet, Il'in, Losev," in A History of Russian Philosophy 1830-1930: Faith, Reason, and the Defense of Human Dignity, ed. G. M. Hamburg and Randall A. Poole (Cambridge: Cambridge University Press, 2010), 326-45.

84 See also S. V. Iakovlev, "Otsenka nigilizma v rabotakh S. L. Franka i A. F. Loseva," in Sbornik "Vekhi" v kontekste russkoi kul'tury, ed. A. A. Takho-Godi and E. A. TakhoGodi, 251-57.

85 Losev, The Dialectics of Myth, 96.

86 See E. Takho-Godi, "Aleksej Losev's Antiutopia," in Aleksei Fedorovich Losev: Philosophy and the Human Sciences, ed. Robert Bird, Studies in East European Thought 56: 2-3 (2004): 243-46.

87 N. Berdiaev, "Predsmertnye mysli Fausta," in Osval'd Spengler i zakat Evropy (Moscow: Bereg, 1922), 64.

88 Losev, "Ia soslan $v$ XX vek...", 402.

89 Ibid., 392.

90 The title of this conversation later became the title of a book addressed to Russian youth, A. F. Losev, Derzanie dukha (Moscow: Plitizdat, 1989).

91 Losev, Derzanie dukha, 296. 
92 Ibid., 294.

93 Ibid.

94 Bibikhin, Aleksei Fedorovich Losev, 170-71.

95 Ibid., 216.

96 Ibid., 170.

97 Ibid., 167.

98 Ibid., 170.

99 Ibid., 233-34.

100 A. F. Losev, Vladimir Solov'v i ego vremia (Moscow: Molodaia gvardiia, 2009), 485-90.

101 Bibikhin, Aleksei Fedorovich Losev, 170. Losev misquotes Angelus Silesius here: his exact words were "without me God may make no single smallest worm."

102 Ibid., 155.

103 Ibid., 170.

104 Ibid., 30.

105 Ibid.

106 This is my decoding of the text. 